\section{Using the DFConhecimento instrument to assess Congolese healthcare professionals' knowledge on sickle cell disease}

\author{
Tina Katamea ${ }^{1}$, Olivier Mukuku' ${ }^{2,3}$, Patient Dinanga Nzala ${ }^{1}$, \\ Bénédicte Malonda Nsasi ${ }^{1}$, Charles Wembonyama Mpoy ${ }^{4}$, Oscar \\ Numbi Luboya ${ }^{1,5}$ and Stanis Okitotsho Wembonyama ${ }^{1,5 *}$ \\ 1'Department of Pediatrics, Faculty of Medicine, University of Lubumbashi, Democratic Republic of \\ the Congo \\ ${ }^{2}$ Institut Supérieur de Techniques Médicales de Lubumbashi, Lubumbashi, Democratic Republic of \\ the Congo \\ ${ }^{3}$ School of Public Health, University of Goma, Goma, Democratic Republic of the Congo \\ ${ }^{4}$ Department of Obstetrics and Gynecology, Faculty of Medicine, University of Lubumbashi, \\ Democratic Republic of the Congo \\ ${ }^{5}$ School of Public Health, University of Lubumbashi, Lubumbashi, Democratic Republic of the \\ Congo
}

\section{Abstract}

Introduction: Despite advances in the management of sickle cell disease (SCD), gaps still exist in the knowledge of healthcare professionals (HCPs) about the disease. The objective of this study was to assess the knowledge of HCPs about SCD.

Methods: This is a cross-sectional study involving 465 HCPs (physicians and nurses) who responded to the DFConhecimento instrument questionnaire. Performance was tested in terms of average score and proportion of correct response for each questionnaire item topic.

Results: The average score for respondents was $4.6 \pm 1.9$ out of a total of 13 points. Proportions of professionals who responded well were greater than $58 \%$ in three topics (Neonatal screening program, Sickle cell conditions, and Sickle cell anemia genotype). In the other topics, rates of good response ranged from $11.6 \%$ to $46.0 \%$. There was a statistical association between best performance and medical title: physicians were more knowledgeable than nurses $(\mathrm{OR}=6.26$; 95\% Cl: 2.69-14.56).

Conclusion: This study highlighted that knowledge of SCD among HCPs is very inadequate. This lack of sufficient information on SCD from HCPs indicates the need to develop continuing education programs.

\section{More Information}

*Address for Correspondence:

Dr. Stanis Okitotsho Wembonyama, School of Public Health, University of Lubumbashi, Lubumbashi, Democratic Republic of the Congo, Email:wembostanis@outlook.fr

Submitted: September 18, 2021 Approved: September 28, 2021 Published: September 29, 2021

How to cite this article: Katamea T, Mukuku O, Nzala PD, Nsasi BM, Mpoy CW, et al. Using the DFConhecimento instrument to assess Congolese healthcare professionals' knowledge on sickle cell disease. J Hematol Clin Res. 2021; 5: 015-020.

DOI: 10.29328/journal.jhcr.1001018

Copyright: @ 2021 Katamea T, et al. This is an open access article distributed under the Creative Commons Attribution License, which permits unrestricted use, distribution, and reproduction in any medium, provided the original work is properly cited.

Keywords: Sickle cell disease; Knowledge; Healthcare professionals; Lubumbashi

Abbreviations: DRC: Democratic Republic of the Congo; HCF: Healthcare Facility; HCP Healthcare Professional; SCD: Sickle Cell Disease; WHO: World Health Organization

\section{D) Check for updates}

(1) open access

\section{Introduction}

Sickle cell disease (SCD) is a hereditary anomaly of the red blood cell characterized by the presence of abnormal haemoglobin S, either in homozygous form (Hb SS) or in association with other abnormal hemoglobins such as $\mathrm{Hb} \mathrm{SC}$ and $\mathrm{Hb} \mathrm{S} \beta$-Thalacemia) [1]. It is characterized by chronic hemolysis, chronic inflammation, immune deficiency, heterogeneous clinical phenotype, and visceral damage. The pathogenic mechanism in SCD is mainly due to chronic inflammation associated with oxidative stress [2]. In this disease, red blood cells have a tendency to deform into a crescent (sickle form) under certain conditions. Its clinical manifestations include chronic anemia, painful vaso-occlusive crises, acute chest syndrome, bone and osteoarticular disorders, stroke, priapism, hepato-biliary, cardiac and renal disorders, and even early mortality $[1,3,4]$.

SCD is considered a public health problem and is a major hereditary disease in the world and the Democratic 
Republic of the Congo (DRC). The incidence of SCD at birth is determined by the prevalence of carriers in the population. In 2010, an estimated 5,788,000 newborn babies were carriers of hemoglobin $\mathrm{S}$ (HbS), of which 5,476,000 were heterozygotes and 312,000 were homozygotes [5]. The DRC is one of the three countries most affected by SCD in the world (after Nigeria and before India) [6]; and in some regions of this country, SCD affects up to $2 \%$ of newborn babies [7-10].

Although the World Health Organization (WHO) recommends public education as a means of reducing sickle cell mortality [11] and despite the large number of people with SCD, the level of knowledge on SCD is still low. In the DRC, various studies have reported poor knowledge of SCD among students and the population [12-14]. Knowledge of SCD is an essential means of preventing and controlling this disease; because healthcare professionals (HCPs) are best equipped to make informed and correct decisions about disease control interventions. Strengthening the education of HCPs in order to acquire sufficient knowledge is a major challenge in relation to this disease in order to actively help those affected to avoid complications and improve their quality of life [15]. Given the lack of tools to assess HCPs' knowledge of SCD in literature, a recent Brazilian study conducted by Diniz, et al. [15] had led to the development and validation of a SCD (DFConhecimento) knowledge tool with Brazilian HCPs.

Several published studies have been conducted to assess the level of knowledge on SCD in the population, but to our knowledge, the approach to assessing HCPs' knowledge on $\mathrm{s}$ SCD has not been studied in our environment. It is necessary to assess the level of knowledge on SCD among HCPs, as an understanding of these factors will help to shape appropriate public health education programs to increase awareness and knowledge of the disease. Thus, it seems appropriate to conduct this survey on knowledge of SCD among Congolese HCPs in Lubumbashi (in the DRC) using the instrument "DFConhecimento".

\section{Methods}

This is an analytical cross-sectional survey conducted in Lubumbashi city, located south of the Haut-Katanga province in the DRC. The city of Lubumbashi is the capital of this province with an estimated population of about 4 million. This city is a focal point in terms of health services for the entire province and surrounding provinces. For the purpose of this study, all physicians and nurses from different healthcare facilities (HCFs) in the city were considered eligible and randomly selected. The exclusion criterion was if an HCP was on vacation or absent from work on the day of data collection or working in a HCF not selected for the study.

This study covered both health centers, general reference hospitals, private clinics, and University Clinics. Data were collected from December 1 to December 31, 2020. Recruited investigators have received extensive training, covering the context of the current investigation, detailed interpretation of the investigation instrument and a simulation investigation test. A total of 10 investigators were recruited. Investigators explained the purpose and procedure of the study and obtained written informed consent from each respondent prior to asking them to complete the questionnaire. On average, the survey lasted 10 to 15 minutes.

In order to collect the data, we used the "DFConhecimento" instrument developed and validated by Diniz, et al. [15] containing a series of 13 key items covering the following topics: neonatal screening; sickle cell anemia genotype; sickle cell traits; factors that contribute to the process of vessel occlusion and sickle cell formation; warning signs of sickle cell disease; use of antibiotics; health issues of adolescents and pregnant women; factors for prevention of leg ulcers, and; health referral services. The questionnaire was closed and self-administered with 4 to 6 assertions for each item, only one of which was considered correct. Respondents were given the opportunity to choose "Don't know" to discourage speculation. For the calculation of the total score of the respondent, " 1 point" was assigned to each correct answer and "0 point" for a wrong answer.

The scores ranged from 0 to 13 . To calculate the final score for the instrument, we used the sum of the correct answers, taking into account the following ranges of knowledge points: $12-13$ corresponding to a precision of more than $90 \%$ (excellent knowledge); 8-11 corresponding to a precision of $60 \%$ to $89 \%$ (good knowledge); and $\geq 7$ corresponding to less than 59\% accuracy (poor knowledge) [15].

A total of 500 questionnaires were distributed and 487 were returned. Of the questionnaires returned, $465 \mathrm{did}$ not contain any missing items and were included for analysis (Figure 1). This represented an effective response rate of $93 \%$.

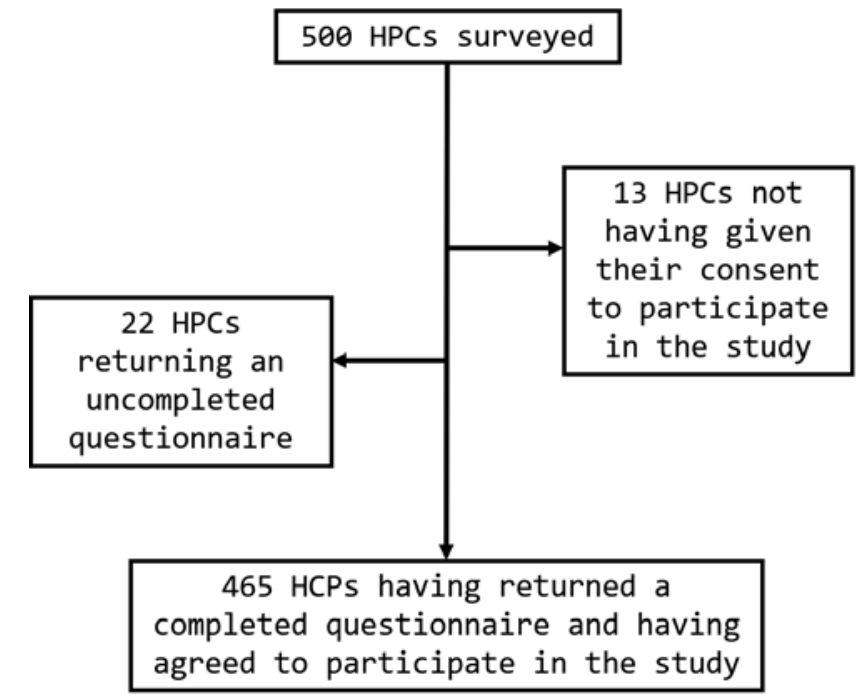

Figure 1: Recruitment of participants. 
The following variables were used to characterize the HCP respondents: age, gender, medical qualification, type of HCF they worked in, years of clinical practice and training related to SCD.

Data collected was entered into Microsoft Excel 2019 and was checked for inconsistencies and errors. The analyzes were performed using STATA software (version 15). The analysis of data included calculations of descriptive statistics, frequencies and calculations of Pearson's Chi square and the exact Fisher test to determine significance. The proportions were calculated for categorical variables and the results were presented in percentages with a $95 \%$ confidence interval using Wilson's score limits.

Demographic and occupational variables (age, gender, medical qualification, type of HCF, professional experience, whether or not they have attended a training session on SCD in the last two years) were analyzed to determine whether participants had significantly different knowledge scores. A value of $p<0,05$ was considered statistically significant.

Ethical considerations have been respected. Participation in the study was voluntary after the signature of free and informed consent. This study has been submitted to the Medical Ethics Committee of the University of Lubumbashi and approved (Approval No.: UNILU/CEM/030/2021).

\section{Results}

A total of 465 HCPs completed the survey, of which 204 (43.81\%) were physicians and 261 (56.13\%) were nurses. The average age of the respondents was $34.16 \pm 8.18$ years and the female sex was $50.11 \%$ (a sex ratio of 1 ). One third $(33.55 \%)$ of respondents worked in private clinics. Respondents had an average number of years of clinical experience of $7.57 \pm 7.26$ years and only about $25 \%$ reported having attended a training session on SCD in the last two years preceding the survey (Table 1 ).

Of the 465 respondents, only 37 (7.96\%; IC 95\%: 5.83\% - 10.78\%) had a good knowledge (knowledge score $\geq 8$ ) and 428 others (92.04\%; IC 95\%: 89.22\% - 94.17\%) had poor knowledge (knowledge score $<8$ ). The average score obtained by respondents was $4.6 \pm 1.9$ points out of a total of 13 points.

The results of the knowledge assessment are presented in Table 2. The proportion of HCPs who responded well was more than 58\% in three topics (Neonatal screening program, Sickle cell conditions, and Sickle cell anemia genotype). In the other topics, the response rates ranged from $11.6 \%$ to $46.0 \%$.

The associations between demographic and occupational variables and knowledge on SCD are presented in Table 3. Almost $15 \%$ of physicians and almost $3 \%$ of nurses had a good knowledge of SCD. The association between medical qualification and knowledge on SCD was statistically significant $(p<0,0001)$, indicating that physicians were significantly more informed than nurses $(\mathrm{OR}=6.26[2.69$ 14.56]).

Furthermore, neither age, gender, type of HCF, clinical experience, nor training session in SCD had any influence on respondents' level of knowledge ( $p>0.05)$.

\section{Discussion}

This study assessed the knowledge of SCD among HCPs in Lubumbashi (DRC). It is recognized that the level of knowledge is indirectly reflected in the quality of health care provided to patients by HCPs [16]. We recall that this is the first Congolese survey to use this instrument developed and validated in Brazil [15].

\begin{tabular}{|c|c|c|}
\hline Variable & Number $(n=465)$ & Percentage \\
\hline \multicolumn{3}{|l|}{ Age (years) } \\
\hline $20-29$ & 151 & 32.47 \\
\hline $30-39$ & 208 & 44.73 \\
\hline$\geq 40$ & 106 & 22.80 \\
\hline Average \pm SD & $34.16 \pm 8.18$ & \\
\hline \multicolumn{3}{|l|}{ Gender } \\
\hline Female & 233 & 50.11 \\
\hline Male & 232 & 49.89 \\
\hline \multicolumn{3}{|l|}{ Medical qualification } \\
\hline Physician & 204 & 43.87 \\
\hline Nurse & 261 & 56.13 \\
\hline \multicolumn{3}{|l|}{ Type of healthcare facility } \\
\hline Health center & 81 & 17.42 \\
\hline General Reference Hospital & 163 & 35.05 \\
\hline Private clinic & 156 & 33.55 \\
\hline University clinic & 65 & 13.98 \\
\hline \multicolumn{3}{|l|}{ Professional experience (years) } \\
\hline$\leq 5$ & 245 & 52.69 \\
\hline $6-10$ & 122 & 26.24 \\
\hline$>10$ & 98 & 21.07 \\
\hline Average \pm SD & $7.57 \pm 7.26$ & \\
\hline \multicolumn{3}{|c|}{$\begin{array}{l}\text { Attending a training session on SCD in the } \\
\text { last two years }\end{array}$} \\
\hline No & 349 & 75.05 \\
\hline Yes & 116 & 24.95 \\
\hline
\end{tabular}

Table 2: Percentages of respondents with correct answers to items on the different topics related to Sickle cell disease.

\begin{tabular}{|c|c|c|}
\hline Item topics & Number $(n=465)$ & $\%(95 \% \mathrm{CI})$ \\
\hline Neonatal Screening Program & 273 & $58.7(54.2-63.1)$ \\
\hline Sickle Cell Condition & 363 & $78.1(74.1-81.6)$ \\
\hline Sickle Cell Anemia Genotype & 411 & $88.4(85.2-91.0)$ \\
\hline Sickle Cell Trait & 74 & $15.9(12.9-19.5)$ \\
\hline Sickle cell disease manifestations & 54 & $11.6(9.0-14.8)$ \\
\hline Vaso-occlusion & 214 & $46.0(41.5-50.6)$ \\
\hline Wactors that favor red blood cells sickling & 160 & $34.4(30.2-38.8)$ \\
\hline Warning Signs & 72 & $15.5(12.5-19.1)$ \\
\hline treatment of sickle cell disease & 86 & $18.5(15.2-22.3)$ \\
\hline Use of antibiotics & 57 & $12.3(9.6-15.6)$ \\
\hline Adolescent Health & 143 & $30.8(26.7-35.1)$ \\
\hline Pregnancy and contraception & 97 & $20.9(17.4-24.8)$ \\
\hline Care for prevention of leg ulcers & 143 & $30.8(26.7-35.1)$ \\
\hline
\end{tabular}




\begin{tabular}{|c|c|c|c|c|c|c|c|}
\hline \multirow{2}{*}{$\begin{array}{c}\text { Variable } \\
\text { Age (years) }\end{array}$} & \multirow[t]{2}{*}{ Total $(N=465)$} & \multicolumn{2}{|c|}{ Good knowledge $(n=37)$} & \multicolumn{2}{|c|}{ Poor knowledge $(n=428)$} & \multirow[t]{2}{*}{ Odds ratio $[95 \% \mathrm{Cl}]$} & \multirow[t]{2}{*}{$p$ - value } \\
\hline & & & & & & & \\
\hline $20-29$ & 151 & 7 & $(4.64 \%)$ & 144 & $(95.36 \%)$ & $0.60[0.21-1.70]$ & 0.478 \\
\hline $30-39$ & 208 & 22 & $(10.58 \%)$ & 186 & $(89.42 \%)$ & $1.45[0.62-3.37]$ & 0.509 \\
\hline$\geq 40$ & 106 & 8 & $(7.55 \%)$ & 98 & $(92.45 \%)$ & 1.00 & \\
\hline \multicolumn{8}{|l|}{ Gender } \\
\hline Female & 233 & 15 & $(6.4 \%)$ & 218 & $(93.56 \%)$ & $0.66[0.33-1.30]$ & 0.297 \\
\hline Male & 232 & 22 & $(9.48 \%)$ & 210 & $(90.52 \%)$ & 1.00 & \\
\hline \multicolumn{8}{|c|}{ Medical qualification } \\
\hline Physician & 204 & 30 & $(14.71 \%)$ & 174 & $(85.29 \%)$ & $6.26[2.69-14.56]$ & $<0.0001$ \\
\hline Nurse & 261 & 7 & $(2.68 \%)$ & 254 & $(97.32 \%)$ & 1.00 & \\
\hline \multicolumn{8}{|c|}{ Type of healthcare facility } \\
\hline Public & 309 & 27 & $(8.74 \%)$ & 282 & $(91.26 \%)$ & $1.40[0.66-2.97]$ & 0.487 \\
\hline Private & 156 & 10 & $(6.41 \%)$ & 146 & $(93.59 \%)$ & 1.00 & \\
\hline \multicolumn{8}{|c|}{ Professional experience (years) } \\
\hline$\leq 5$ & 245 & 22 & $(8.98 \%)$ & 223 & $(91.02 \%)$ & $1.35[0.68-2.67]$ & 0.491 \\
\hline$>5$ & 220 & 15 & $(6.12 \%)$ & 205 & $(93.18 \%)$ & 1.00 & \\
\hline \multicolumn{8}{|c|}{ Attending a training session on SCD in the last two years } \\
\hline Yes & 116 & 11 & $(9.48 \%)$ & 105 & $(90.52 \%)$ & $1.30[0.62-2.72]$ & 0.615 \\
\hline No & 349 & 26 & $(7.45 \%)$ & 323 & $(92.55 \%)$ & 1.00 & \\
\hline
\end{tabular}

The present study reports a small proportion of HCPs with good knowledge (7.96\%) in general. Specifically, only in three topics (Neonatal screening program, Sickle cell conditions, and Sickle cell anemia genotype) did the proportion of HCPs who responded well reach more than 58\%. In the others topics, rates of good responses ranged from $11.6 \%$ to $46.0 \%$ (Table 2).

Given that the DRC is the second most affected country in Africa (after Nigeria), with an estimated prevalence of $2 \%$ among newborns $[7,8]$, but ranging from $3.47 \%$ to $7.1 \%$ in Lubumbashi $[9,10]$, it would be expected that a large number of HCPs could have a good knowledge of SCD and its neonatal screening. This survey shows that a large number of participants did not respond correctly $(7.96 \%$ of good knowledge) although the survey questions are relatively simple.

Several studies assessing the level of knowledge about SCD had shown that physicians and nurses had poor knowledge [17-21]. The low percentage of correct answers from physicians and nurses regarding the majority of questions asked shows that these HCPs have insufficient understanding of how to help sickle-cell patients, indirectly leading to a poor outcome in terms of assistance to sicklecell patients. It follows from this finding that these HCPs are included in the lifelong learning process on SCD. Physicians and nurses offer great potential in terms of health promotion and preventive action [17].

In terms of the knowledge of the HCPs studied on SCD, physicians had a significantly higher rate of good knowledge than nurses. Similar findings have been reported in studies on the assessment of knowledge of Brazilian HCPs about SCD [21]. Most of the time, nurses are the first to come into contact with the patient, taking vital signs and subsidizing medical diagnosis; they are still working towards maintaining an interdisciplinary team [21]. This is why they must be included in the knowledge update program.

The study reported that $75 \%$ of the HCPs reported not having attended a training session on SCD. This observation is superimposed on that made by Barroso, et al. [21] who had noticed that a large number of HCPs did not have a SCD training (94.2\%).

By comparing the level of knowledge on SCD with the number of years of clinical experience and the fact of having followed training on SCD, it was observed that there was no statistically significant association. This shows that there is an urgent and emerging need to update and train HCPs, with regard to all topics on SCD, with a focus on the tasks of each HCP, with the aim of making an early diagnosis and guiding care to improve the quality of life of sickle-cell patients.

In the knowledge assessment on the treatment to be used, less than $20 \%$ of the participants responded correctly by citing different medicines recommended for sickle cell patients. Although it is a chronic incurable disease, SCD is treatable. For example, it is very important to inform HCPs and the population that early treatment is provably increasing the survival of sickle cell patients and improving the quality of life [22]. Improving the survival and quality of life of these patients is based on general and preventive measures. These include good nutrition, prophylaxis, early diagnosis and treatment of infections, vaccination and penicillin use, maintenance of good hydration, and prevention of adverse climatic conditions [21].

Lack of information about treatment and care related to SCD prevents sickle cell patients from continuing with care by leading them to adopt inappropriate measures or even to seek out unrecommended treatments. Literature data show that early diagnosis (especially neonatal period) and 
appropriate treatment greatly improve survival and quality of life in sickle cell patients [23].

The results of this knowledge assessment study can be used to identify areas where training programs will need to be intensified [24]. Education based on continuous learning is a necessary condition for the development of the subject in terms of improved care. The pursuit of the continuity of education for HCPs, through postgraduate courses and also free training, must be not only an initiative of the institution to which they are linked, but above all a commitment to everyone aiming at personal, professional and social transformation [21]. This study has shown that physicians and nurses in our community lack sufficient information in the field of SCD. It is the responsibility of the health authorities to ensure the continuing training, qualification and education of these HCPs during their service [25]. In order to produce satisfactory results, HCPs need a continuous and effective training and information process to be able to meet the needs created by the dynamism of the problems.

\section{Conclusion}

This study highlighted that health care providers' knowledge of SCD is poor. This lack of sufficient information on SCD from health professionals indicates the need to provide continuous training for HCPs in order to improve their level of knowledge, but also to provide accurate and correct information and adequate care for sickle cell patients and their relatives.

\section{References}

1. Makani J, Ofori-Acquah SF, Nnodu O, Wonkam A, OheneFrempong K. Sickle cell disease: new opportunities and challenges in Africa. Scienti World J. 2013; 2013: 193252.

PubMed: https://pubmed.ncbi.nlm.nih.gov/25143960/

2. Mukuku O, Sungu JK, Mutombo AM, Mawaw PM, Aloni MN, et al. Albumin, copper, manganese and cobalt levels in children suffering from sickle cell anemia at Kasumbalesa, in Democratic Republic of Congo. BMC Hematol. 2018; 18: 23.

PubMed: https://www.ncbi.nlm.nih.gov/pmc/articles/PMC6127910/

3. Bello-Manga H, DeBaun MR, Kassim AA. Epidemiology and treatment of relative anemia in children with sickle cell disease in sub-Saharan Africa. Expert Rev Hematol. 2016; 9: 1031-1042.

PubMed: https://pubmed.ncbi.nIm.nih.gov/27677923/

4. Connes P. Physiopathologie de la drépanocytose. In: de Montalembert, Allali S, Brousse V, Marchetti MT. La drépanocytose de l'enfant et l'adolescent. Paris: Elsevier Masson; 2020.

5. Piel FB, Patil AP, Howes RE, Nyangiri OA, Gething PW, et al. Global epidemiology of sickle haemoglobin in neonates: a contemporary geostatistical model-based map and population estimates. Lancet. 2013; 381: 142-151.

PubMed: https://pubmed.ncbi.nlm.nih.gov/23103089/

6. Williams TN. Sickle cell disease in sub-Saharan Africa. Hematol Oncol Clin North Am. 2016; 30: 343-358.

PubMed: https://pubmed.ncbi.nlm.nih.gov/27040958/

7. Tshilolo L, Aissi LM, Lukusa D, Kinsiama C, Wembonyama S, et al. Neonatal screening for sickle cell anemia in the Democratic Republic of the Congo: experience from a pioneer project on 31204 newborns.
J Clin Pathol. 2009; 62: 35-38.

PubMed: https://pubmed.ncbi.nlm.nih.gov/19103857/

8. Agasa B, Bosunga K, Opara A, Tshilumba K, Dupont E, et al. Prevalence of sickle cell disease in a northeastern of the Democratic Republic of Congo: What impact on transfusion policy? Transfus Med. 2010; 20: 62-65.

PubMed: https://pubmed.ncbi.nlm.nih.gov/19712051

9. Shongo MYP, Mukuku O. Dépistage néonatal de la drépanocytose à Lubumbashi, République Démocratique du Congo. Revue de I'Infirmier Congolais. 2018; 2: 62-63.

10. Katamea T, Mukuku O, Wembonyama SO. Newborn screening for sickle cell disease in Lubumbashi city, Democratic Republic of the Congo: a preliminary study on an update of the disease prevalence. Bri J Haematol. 2021; 193: 31.

11. OMS. Comité régional de l'Afrique. Drépanocytose: unestratégie pour la région africaine de l'OMS. Soixantièmesession. Malabo, Guinée équatoriale, 30 août-3 septembre 2010. 2021.

PubMed: https://apps.who.int/iris/handle/10665/1727

12. Kambale-Kombi $P$, Marini Djang'eing'a R, Alworong'a Opara JP, Tonen-Wolyec S, Kayembe Tshilumba C, et al. Students' knowledge on sickle cell disease in Kisangani, Democratic Republic of the Congo. Hematology. 2020; 25: 91-94.

PubMed: https://pubmed.ncbi.nlm.nih.gov/32070266/

13. Mukinayi BM, Kalenda DK, Mbelu S, Gulbis B. Connaissances et comportements de 50 familles congolaises concernées par la drépanocytose: une enquête locale. The Pan Afri Med J. 2018; 29: 24. PubMed: https://www.ncbi.nlm.nih.gov/pmc/articles/PMC5987149/

14. Batina SA, Kambale PK, Sabiti MP, Kayembe CT. Barriers to healthcare for sickle cell disease patients in the DemocraticRepublic Congo. Afr J Health Issues. 2017; 1: 2.

15. Diniz KKS, Pagano AS, Fernandes APPC, Reis IA, Pinheiro LG, et al. Development and validation of an instrument to assess Brazilian healthcare professional providers' knowledge on sickle cell disease. Hematol Transfus Cell Ther. 2019; 41: 145-152. PubMed: https://pubmed.ncbi.nlm.nih.gov/31084764/

16. Gomes LMX, Vieira MM, Reis TC, de Andrade-Brabosa TL, CaldeiraAP. Understanding of technical education level professionals regarding sickle cell disease: a descriptive study. Online Brazilian J Nurs. 2013; 12: 482-490.

17. Xavier-Gomes LM, Vieira MM, Reis TC, Andrade-Barbosa TL, Caldeira AP. Knowledge of family health program practitioners in Brazil about sickle cell disease: a descriptive, cross-sectional study. BMC Fam Pract. 2011; 12: 89.

PubMed: https://pubmed.ncbi.nlm.nih.gov/21854618/

18. Weinreich SS, Klerk ESML, Rijmen F, Cornel MC, Kinderen M, et al. Raising awareness of carrier testing for hereditary haemoglobinopathies in high-risk ethnic groups in the Netherlands: a pilot study among the general public and primary care providers. BMC Public Health. 2009; 9: 338.

PubMed: https://pubmed.ncbi.nlm.nih.gov/19754950/

19. Dennis-Antwi JA, Dyson S, Ohene-Frempong K. Healthcare provision for sickle cell disease in Ghana: challenges for the African context. Diversity in Health and Social Care. 2008; 5: 241-54.

20. Ratanawongsa N, Haywood Jr C, Bediako SM, Lakshmi L, Lanzkron S et al. Health care provider attitudes toward patients with acute vasoocclusive crisis due to sickle cell disease: Development of a scale. Patient Educ Couns. 2009; 76: 272-278.

PubMed: https://pubmed.ncbi.nlm.nih.gov/19233587/

21. Barroso LMFM, Araújo TME, Alves BE, de Carvalho MDC. Professional knowledge of the family health strategy on sickle-cell disease. Revista de Pesquisa Cuidado é Fundamental Online. 2013; 5: 9-19.

22. Tshilolo L, Tomlinson G, Williams TN, Santos B, Olupot-Olupot $P$, et al. 
Hydroxyurea for children with sickle cell anemia in sub-Saharan Africa. New Engl J Med. 2019; 380: 121-131.

PubMed: https://pubmed.ncbi.nIm.nih.gov/30501550/

23. Bello-Manga H, DeBaun MR, Kassim AA. Epidemiology and treatment of relative anemia in children with sickle cell disease in sub-Saharan Africa. Expert Rev Hematol. 2016; 9: 1031-1042.

PubMed: https://pubmed.ncbi.nlm.nih.gov/27677923/
24. Jenerette CM, Brewer CA, Silva S, Tanabe P. Does attendance at a sickle cell educational conference improve clinician knowledge and attitude toward patients with sickle cell disease? Pain Manag Nur. 2016; 17: 226-234.

PubMed: https://pubmed.ncbi.nlm.nih.gov/27283268/

25. Nascimento EPL, Correa CRS. O agente comunitário de saúde: formação, inserção e práticas. Cad saúde pública. 2008; 24: 1304-1313. 